\title{
Influence Of Spirituality In Pediatric Cancer Management: A Systematic Review \\ [REVIN
}

Camilla Barros Meireles', Laís Chaves Maia1, Victoria Aline Linhares Miná1, Maria do Socorro Martins Cardoso Novais ${ }^{2}$, Jorge André Cartaxo Peixoto ${ }^{2}$, Maria Auxiliadora Brasil Sampaio Cartaxo2 ${ }^{2}$, João Marcos Ferreira de Lima ${ }^{3}$, Francisco Antônio Vieira dos Santos ${ }^{3}$, Cicera Janielly de Matos Cassiano ${ }^{3}$, Patricia Gonçalves Pinheiro ${ }^{3}$, Modesto Leite Rolim Neto ${ }^{1,2,3}$

\section{Abstract}

Context: Pediatric cancer is a wide challenge for the patients, family and health care team. They must deal with anxiety, distress, and pain. Thereby, to find meaning for this journey, they use different coping strategies, among which, spirituality appears to be a way, providing well-being and hope.

Objective: The purpose of this review was to analyze the influence of spirituality in childhood cancer care, involving biopsychosocial aspects of child, family, and health professionals facing cancer.

Data Sources: To achieve this goal, a systematic review of literature was conducted via electronic databases Scopus, MEDLINE and PubMed using Medical Subject Headings (MeSH) terms: "spirituality", "neoplasm" and "pediatric".

Study Selection: Through this search it was found 65 articles. After analyzing them by abstract 13 met the eligibility criteria and were entirely read before included in the final sample.

Data Extractions: Sys Most of the studies stated that spirituality helps pediatric patients and their families to find a positive meaning from cancer experience, turning better the management of child. Besides, health practitioners may be able to facilitate this process working as a multidisciplinary team, providing to patient an unabridged care.
1 Faculty of Medicine, Federal University of Cariri, UFCA, Barbalha, Ceará, Brazil.

2 Pos-graduation Program in Health Sciences, Faculty of Medicine of $A B C$.

3 Faculty of Medicine, Estacio -FMJ, Juazeiro do Norte, Ceara, Brazil.

\section{Contact information:}

Modesto Leite Rolim Neto

” modestorolim@yahoo.com.br

Keywords

Cancer, Pediatric, Spirituality 
Results: In this context, previous studies stated that when health care team respects patient's spirituality their connection becomes stronger allowing confidence to take place, promoting treatment engagement. Spirituality also revealed to be a psychological support that acts improving life's quality.

Conclusion: So, it is necessary to promote a deep discussion about this topic since graduation, providing humanized care to child with cancer by qualified health practitioners.

\section{Introduction}

Childhood cancer has a profound impact on the lives of children and their families and requires them to face many stressors and challenges. [1] Pediatric palliative care, such as spirituality, became a priority in health care field when the Initiative for Pediatric Palliative Care was established in 1998 as an education research forum for pediatric palliative care $[2,3]$ and have been gaining acceptance throughout the world since then. [4]

Spirituality will be defined during this study as "an attachment to or regard for things of the spirit as opposed to material or worldly interests" [5] and faith will be defined as "giving credit to, believing, trusting." $[5,6]$

Haase [7] has proposed that hope and spiritual perspective are important to helping patients derive positive meaning from their cancer experience [8] and Palliative care seeks to relieve the emotional, social, and spiritual distress produced by these life-limiting conditions, to assist in complex decision making, and to enhance quality of life. $[8,9,10]$

Parents who have a child with a life-threatening illness, such as cancer, are experiencing a tragedy. [2] From the moment of diagnosis, through the many treatment modalities, until remission or death, a parent is consumed with his or her child's illness, treatment, and finding a cure. [11] Parents require emotional, informational, spiritual, practical, physi- cal, and psychosocial support to make it through this time of crisis. [12]

Physicians may be able to facilitate formulation of peace of mind by giving parents high-quality medical information, including prognostic information, and facilitating parents' trust. [13] As a result physician should work in a multidisciplinary team consisting of registered nurses, child life specialists, a psychologist, social worker, pharmacist, clinical dietitian, data manager, occupational therapist, physiotherapist, and secretarial support. [12]

The purpose of this study was to analyze the influence of spirituality in childhood cancer care, involving biopsychosocial aspects of child, family, and health care team facing the disease.

\section{Methods}

The present study is a systematic review of literature. At first, a search of the literature was conducted via international electronic databases Scopus, MEDLINE and PubMed in 10 May 2014. The search terms browsed in databases were "spirituality", "neoplasm" and "pediatric" using Medical Subject Headings (MeSH) terms with no time limit. For assessing risk of bias of individual studies, where a title or abstract seemed to describe a study eligible for inclusion, the full article was examined to assess its relevance based on the inclusion criteria. Three 
independent researchers (CM, LC, VM) conducted a three-step literature search. Any discrepancies between the three reviewers who, blind to each other, examined the studies for the possible inclusion were resolved by consultations with two senior authors (MR, CS).

The article analysis followed previously determined eligibility criteria. The studies must have met all the following criteria for inclusion: (1) manuscripts written in English; (2) original articles with online accessible full text available in Coordination of Improvement of Higher Education Personnel (CAPES) Journal Portal, a virtual library linked to Brazil's Ministry of Education and subjected to content subscription; (3) articles about spirituality in management of pediatric cancer; and (4) prospective or retrospective observational (analytical or descriptive, except case reports), experimental or quasi-experimental studies.

We adopted the following exclusion criteria: (1) other designs, such as case reports, series of cases, review of literature, and commentaries; (2) non-original studies, including editorials, reviews, prefaces, brief communications, and letters to the editor; (3) full text not available in CAPES; (4) author's name not disclosed; and (5) out of context.

Then, each paper in the sample was read in entirety, and data elements were then extracted and entered into a matrix that included authors, publication year, description of the study sample, and main findings. Some of the studies dealt not only with spirituality influence on child cancer patients, but also in their parents, close relatives and health care team.

Thus, to provide a better analysis, the next phase involved comparing the studies and grouping, to facilitate our study, the results regarding the studied subject were classified into four categories: how spirituality affects the health care team and the parents; spirituality bringing other motivating feelings; spirituality helping in difficult decisions; and how spirituality affects the patient.
To achieve a high standard of reporting we have adopted 'Preferred Reporting Items for Systematic Reviews and Meta-Analyses' (PRISMA) guidelines. The PRISMA Statement consists of a 27-item checklist and a four-phase flow diagram for reporting in systematic reviews and meta-analyses. PRISMA includes the broader effort to improve the reporting of different types of health research, and in turn to improve the quality of research used in decisionmaking in healthcare. Beside this we based our eligibility criteria in PICO (Patient, Problem, Population; Intervention; Comparison, Control, Comparator; Outcomes) process.

\section{Results}

Initially, the aforementioned search strategies resulted in 65 references. After analyzing title and abstract according to the eligibility criteria 13 articles were included in the final sample. From this total, fifteen (23.0\%) manuscripts were found in Scopus database, twenty-five $(38,46 \%)$ in PubMed database and twenty-five $(38,46 \%)$ in MEDLINE databases. Figure 1.

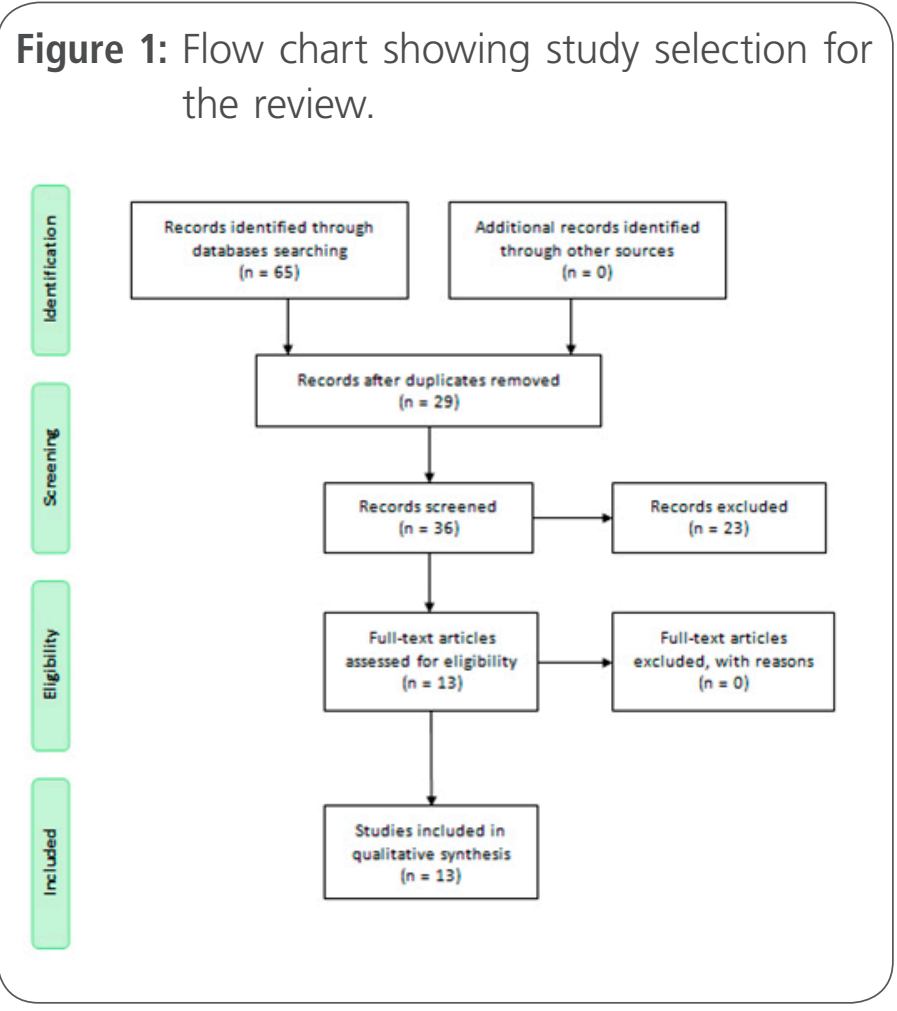


Table 1 synthetize all studies included in the final sample and all data elements used during the data analysis process. The 13 studies were distributed in the previously determined four categories as follows: how spirituality affects the health care team and the parents; spirituality bringing other motivating feelings; spirituality helping in difficult decisions; and how spirituality affects the patient.

\section{(Table 1)}

Table 1. Spirituality in management of pediatric cancer: studies and main findings.

\begin{tabular}{|c|c|c|c|}
\hline Authors & Journal & Category & Main Findings \\
\hline $\begin{array}{l}\text { Feyh JM, Levine } \\
\text { GE, Clay K [2] }\end{array}$ & $\begin{array}{l}\text { Am J Hosp } \\
\text { Palliat Care }\end{array}$ & $\begin{array}{l}\text { How spirituality } \\
\text { affects the health } \\
\text { care team and the } \\
\text { parents }\end{array}$ & $\begin{array}{l}\text { Findings from the data suggested a process of finding meaning } \\
\text { which helps close relatives to let go of what they cannot control } \\
\text { while holding on to what they can control. Social change } \\
\text { implications of this study may include improving health care } \\
\text { programming for close relatives utilizing supportive-expressive } \\
\text { measures. This programming may promote mental health of } \\
\text { the close relatives who will learn to deal with their adjustment } \\
\text { difficulties and improve their coping skills. }\end{array}$ \\
\hline $\begin{array}{l}\text { Tamburro RF, } \\
\text { Shaffer } M L \text {, } \\
\text { Hahnlen } N C \text {, et } \\
\text { al1[4] }\end{array}$ & J Palliat Med & $\begin{array}{l}\text { Spirituality helping in } \\
\text { difficult decisions }\end{array}$ & $\begin{array}{l}\text { Children with complex, life-limiting conditions and their families } \\
\text { referred to a palliative care service commonly verbalize goals } \\
\text { related to health maintenance and independence. Anticipating } \\
\text { this expectation may foster communication and improve patient } \\
\text { care. }\end{array}$ \\
\hline $\begin{array}{l}\text { Kamper R, } \\
\text { Van Cleve L, } \\
\text { SavedraM [15] }\end{array}$ & $\begin{array}{l}\text { J Spec Pediatr } \\
\text { Nurs }\end{array}$ & $\begin{array}{l}\text { How spirituality } \\
\text { affects the patient }\end{array}$ & $\begin{array}{l}\text { Children's care will be enhanced when given the opportunity to } \\
\text { express their spiritual and relational concerns. }\end{array}$ \\
\hline $\begin{array}{l}\text { Zelcer S, } \\
\text { Cataudella } D, \\
\text { Cairney } A E \text {, et } \\
\quad \text { al [16] }\end{array}$ & $\begin{array}{l}\text { Arch Pediatr } \\
\text { Adolesc Med }\end{array}$ & $\begin{array}{l}\text { Spirituality bringing } \\
\text { other motivating } \\
\text { feelings }\end{array}$ & $\begin{array}{l}\text { The neurologic deterioration that characterizes the dying } \\
\text { trajectory of children with brain tumors may create significant } \\
\text { challenges for health care professionals and the children's parents, } \\
\text { supporting the need for increased awareness of the distinct issues } \\
\text { in the palliative care of children with brain tumors and for early } \\
\text { anticipatory guidance provided for families. }\end{array}$ \\
\hline $\begin{array}{l}\text { Hinds PS, Oakes } \\
\text { LL, Hicks J, et al } \\
\qquad 17]\end{array}$ & J Clin Oncol & $\begin{array}{l}\text { Spirituality helping in } \\
\text { difficult decisions }\end{array}$ & $\begin{array}{l}\text { The definition and the strategies may be used to guide clinicians } \\
\text { in helping parents fulfill the good parent role and take comfort } \\
\text { afterward in having acted as a good parent. }\end{array}$ \\
\hline $\begin{array}{l}\text { Mack JW, Wolfe } \\
\text { J, Cook EF, et al } \\
\qquad 13]\end{array}$ & $\begin{array}{l}\text { Arch Pediatr } \\
\text { Adolesc Med }\end{array}$ & $\begin{array}{l}\text { Spirituality bringing } \\
\text { other motivating } \\
\text { feelings }\end{array}$ & $\begin{array}{l}\text { Physicians may be able to facilitate formulation of peace of mind } \\
\text { by giving parents high-quality medical information, including } \\
\text { prognostic information, and facilitating parents' trust. }\end{array}$ \\
\hline $\begin{array}{l}\text { Servitzoglou M, } \\
\text { Papadatou D, } \\
\text { Tsiantis I,et al } \\
\quad[18]\end{array}$ & J Clin Oncol & $\begin{array}{l}\text { How spirituality } \\
\text { affects the patient }\end{array}$ & $\begin{array}{l}\text { Generally, patients seem to adapt well and focus on the positive } \\
\text { aspects of their cancer experience, which enhances the meaning } \\
\text { and quality of their life. }\end{array}$ \\
\hline $\begin{array}{l}\text { Hendricks- } \\
\text { Ferguson V [8] }\end{array}$ & $\begin{array}{l}\text { West J Nurs } \\
\text { Res }\end{array}$ & $\begin{array}{l}\text { How spirituality } \\
\text { affects the patient. }\end{array}$ & $\begin{array}{l}\text { Adolescents in the first two time periods reported significantly } \\
\text { higher levels of spiritual well-being (SWB), religious well-being } \\
\text { (RWB), and existential well-being (EWB) than those in subsequent } \\
\text { time periods. Hope did not significantly vary over time. Hence, } \\
\text { time since diagnosis may influence adolescents' levels of SWB and } \\
\text { its dimensions during the cancer experience. }\end{array}$ \\
\hline
\end{tabular}




\begin{tabular}{|c|c|c|}
\hline $\begin{array}{c}\text { Kerr LM, } \\
\text { Harrison MB, } \\
\text { Medves J, et al } \\
{[12]}\end{array}$ & $\begin{array}{c}\text { J Pediatr Oncol } \\
\text { Nurs }\end{array}$ & $\begin{array}{l}\text { How spirituality } \\
\text { affects the health } \\
\text { care team and the } \\
\text { parents }\end{array}$ \\
\hline $\begin{array}{c}\text { _im J, Wong M, } \\
\text { Chan MY, et al } \\
{[4]}\end{array}$ & $\begin{array}{l}\text { Ann Acad } \\
\text { Med } \\
\text { Singapore }\end{array}$ & $\begin{array}{l}\text { How spirituality } \\
\text { affects the health } \\
\text { care team and the } \\
\text { parents }\end{array}$ \\
\hline
\end{tabular}

Hendricks- J Pediatr Oncol How spirituality Ferguson V19 Nurs affects the patient

Schneider MA, Mannell RC [6]

Issues Compr Pediatr Nurs

How spirituality affects the health care team and the parents
With further refinement, the use of the conceptual framework will provide a methodology for planning care based on the individual needs identified by parents of children with cancer.

A substantial proportion of paediatric cancer patients utilises CAM therapies, often without their physician's knowledge. Healthcare providers need to remain cognisant of the potential implications of CAM usage in order to proactively counsel patients.

Developmental phase and/or gender may influence adolescents levels of hope, spiritual well-being, religious well-being, and existential well-being as they cope during the cancer experience. The nurse should consider developmental phase and gender when planning interventions to foster hope and spiritual wellbeing in adolescents' adaptations to the cancer experience.

In particular, spirituality's influence was described in both a religious and secularized manner with both aspects having a positive influence on coping behaviors among these parents. Health care professionals and nurses in particular have a role to play in facilitating access to spiritual resources as well as acknowledging and accepting the spiritual practices of the families they serve.

This substantive theory provided an understanding of how children and families used the process of keeping the spirit alive in response to them having to experience the phenomenon of the cancer: "getting through all the rough spots."
Woodgate RL, J Pediatr Oncol How spirituality Degner LF \{1] Nurs affects the health care team and the parents

\section{Spirituality in patients' cancer journey}

This theme captured the importance of children continuing to "live their lives" despite the hardships they were enduring. [16] For example, patients with cancer who are able to develop a sense of peace and equanimity in their cancer experience tend to have better quality of life $[13,27]$ and better psychological health. [13, 26, 27, 28, 29]

In children, spirituality has been defined as the ability to derive personal value and transcend beyond the self through relationships with others. [30, 15] As a result, Kamper $R$ et al [15] searchers elucidates that children's view their parents as a "guardians" of sorts by downplaying symptoms, "acting" like they felt better, and having a cheerful demeanor as they protected their parents/family members. It is like there would always be the scars to remind them 
of the cancer experience, but by getting through, families were better able to cope. $[15,1]$

The majority of children sought out God and/or a higher power by praying for/requesting to feel better, be out of the hospital, and care for family and friends. [15] During this process, it was the spirit that helped children and families continue living, even in the face of death.1 Keeping the spirit alive referred to the children's and families' ability to not let the cancer experience get the better of them making the cancer experience something more tolerable. [1]

Additionally, according to Woodgate RL et al [1] children and families associated the spirit with the following four characteristics: (1) a particular mindset or state of mind; (2) a force within or a need to persevere; (3) a passion or wonder for living; and (4) a need to feel connected. The spirit as noted by one child was just not one thing but was "a combination of positive attitude, determination, and perseverance". [1]

Parry C, et al [31] have suggested that the process of psychospiritual growth in adolescent survivors of cancer may be related to long-term psychosocial well-being. [8] Survivors of childhood cancer, generally, seem to adapt well and focus on the positive aspects of their cancer experience by their spiritual growth. They described self as more mature than their peers and as being able to manage major difficulties in life with increased self-confidence, determination, and resilience. [18] As suggested by other researchers, it is believed that the fact that they survived such a devastating experience enhanced their appreciation of life, as a result of which they refused to worry about few physical limitations. [32,18]

According to Tamburro, RF et al [14] fifteen of the 39 (38\%) patients/families that acknowledged that spirituality was important to them opted for some limitation of support as compared with only 2 of the $9(22 \%)$ patients/families that expressed that spirituality was not important to them. [14]

\section{Regarding adolescents}

Fowler [33] incorporated these ideas into his Stages of Faith and asserted that during the school-age years, children's social interactions and experiences are closely related to what they think about religion.15 Additionally, developmental phase and/or gender may influence adolescents' levels of hope, spiritual well-being, religious well-being, and existential well-being as they cope during the cancer experience. For example, girls are more hopeful and reported higher spiritual well-being than boys. [14] Thus, adolescent boys with cancer may have more difficulty adapting to cancer than girls. [34, 14]

The difference in hope may also be attributed to the cognitive maturity of the middle adolescent compared with the early adolescent. [14] The middle adolescents may have sought and/or used religion more to cope with the uncertainty of their illness and to search for answers to questions related to their illness (Why me? What will happen if I die? Will I go to heaven?). [14]

Tebbi CK, Mallon JC, Richards ME [35] indicated that the majority of the adolescents reported a belief in God as a source of support for coping with their illness and that religion offered a sense of security in the face of death. [8] This faith was perceived to be a source of comfort during trying times. The act of prayer, in particular, was perceived to be extremely powerful and important. [6] The adolescents prayed for "forgiveness of sins" and asked for God's love, energy and care. Sometimes, adolescents find another ways to feel closer to god, like play an instrument or ask relatives to pray for them.15

However, religion is not the only means through which people foster their spirituality. For many, faith has a secular or nonreligious component that can be equally important in satisfying their spiritual needs. [36, 6]

Also, Landolt MA, Vollrath M, Ribi K [37] found lower socioeconomic status to be associated with more use of religious coping strategies among 
school-age children and adolescents from 3 populations (accidents, newly diagnosed cancer, and diabetes). [37, 19]

Therefore, pediatric cancer experience may create significant challenges for health care professionals and the children's parents, supporting the need for increased awareness of the distinct issues in the palliative care of children with cancer and for early anticipatory guidance provided for families. [16]

\section{Spirituality helping family cope with the pediatric cancer experience}

Despite increasing survivorship, childhood cancer is nonetheless still a very traumatic phenomenon. To the parents it could be like to live through and bear witness to their child actively dying. [16] Thus, parents describe the diagnosis and treatment of child with cancer as one of the most stressful times in their lives. [38, 39, 40, 41, 42, 43]

The spiritual beliefs possessed by the parents appeared to offer a great deal of comfort to them while dealing with their child's illness. Spirituality was described as being highly personal and extremely powerful in its own right [6]. One factor that helps parents to make these decisions and remain satisfied with them afterward is deciding as they believe a good parent would decide. All the time two things are passing by these parents' minds "doing what a good parent would do" or "deciding as a good parent would." [17]

The qualitatively derived definition of being a good parent to a child with incurable cancer is: making prudent decisions in best interest of child (even when parent would prefer different course); being a good life example: trying to live life that teaches child to behave in positive ways; letting the lord lead: Bringing child up to know God and find comfort in his constant presence; and letting child know that parent prays for child every day. [17]

Some parents discussed the inherent power and importance of prayer as an act in and of itself. For those individuals identifying themselves as being spiritual, prayer was believed to be a powerful tool that assisted them in their ability to cope and in their child's ability to heal. Others described this power of prayer in terms of it actually affecting change in their children by having a direct, positive impact on their health or a positive light. It was evident that most of these men and women were willing to entrust their prayers to God and believed this practice to be a positive way in which they could support their child who was ill. [6]

In addition, parents of children who have died of cancer report that their sense of having been a good parent at the end of their child's life helps them to emotionally survive the experience and the child's loss. [44] Likewise, among parents whose child died in a pediatric intensive care unit, 73\% identified faith-based sources of comfort at the end of their child's life. $[42,17]$

Besides, parents are faced with challenges in ensuring that their child's pain is managed, their psychological and spiritual needs are being met, and their quality of life is maintained until death. [2] Having "something else to try" before giving up seems to instill a sense of hope and perhaps gives families the sense that they are still active in trying to cure the illness. [6] As a result, parents at times viewed the cancer experience either as a challenge and test of one's strength, or as an overall loss and devastating defeat. [1]

In this context, parent's inability to alleviate the pain and difficulties at death creates long-term emotional turmoil.2 Kreichbergs $U$, et al [46] found that the inability to alleviate the physical pain of a child near death and a difficult moment of death affected parents years after the child's death. Spirituality may help this context promoting mental health for the close relatives who will learn to deal with their adjustment difficulties and improve their coping skills. [2] Suggests palliative care should begin at the time of diagnosis and continue concurrently with curative therapy, taking a more predominant role at end of life. $[8,47]$ 
Relatives' challenges are far to end in this topic. They still have to balance their own jobs, financial stressors, and care of their other children. [16] In addition they usually have to deal with concerns about their financial situation, adapting it to a new life style. [12] Sometimes they overlook these aspects and focus only on giving support. Giving support also provided a sense of value to their experience. These close relatives are highly reliant on their faith and their belief in God to get them through this process. [2]

According to Jenkins RA, Pargament KI [48] most parents described their spirituality as being an effective coping mechanism. The strength of spiritual beliefs is in their ability to serve multiple purposes including support, solace, and personal meaning. [6] In Schneider MA, Mannell RC [6] interview survey respondents reported that is a higher power that controls everything, so when things get really bad God is there supporting them, keeping them strong.

Additionally, based on the definitions provided in the The Strength of the Ontario framework (SCNF), the need "working through feelings of death and dying" could be classified as either a spiritual need (death and dying) or an emotional need (feelings). [12] That's another important point in parents pediatric cancer experience: talking about death and dying with their child. [16] Parents observed that their child was aware of and accepted the reality of the advanced stage of illness before they were. Often the child guided the parents through the process of closure and saying goodbye. [16]

As the illness experience induce existential crisis to the family; the diagnosis of cancer and the possibility of death call into question personal beliefs about life's meaning. [49, 50, 13] As a result some decisions may be regret by the parents. Some parents who had not discussed death with their child expressed regret in not doing so. Reasons as to why they did not talk to their child about death included being in denial and not wanting to destroy the hope they and their child had for a cure. [16] This is not to say that these same parents did not experience doubts surrounding their faith and its ultimate role in the health of their child. [6]

Another coping mechanism identified by parents was finding spiritual strength through maintaining hope as well as from the courage and resilience of their child. [16] Faith was believed to have been a tremendous source of support for most of these parents throughout their childhood cancer journey. 6 In addition, spirituality have helped making decisions like wanting their child to die in his or her own home, surrounded by loved ones, and parents having the desire to be the primary care giver for their child up to the end.[16]

\section{Spirituality helping health care team supporting families at cancer journey}

The interaction between the child's health care sta$\mathrm{ff}$, the child, and the family is vital to the parents' beliefs, that care for their child is acceptable and responsive. [51,2] Understanding this fact and exploring the means to ease this psychological difficult trajectory should be paramount to the professional caregivers involved with the family's care. [6] In the few studies that have addressed caregiver spirituality in relation to children with life threatening illnesses, religion has been described as serving as something participants relied on to cope more constructively with the illness. [52, 53, 54]

Clinicians must be aware of the resilience of our patients and must try to include them, when possible, in health care decision making. [16] It is essential for health care professionals to acknowledge the importance of spirituality and faith for this particular patient population. [6] A better understanding of what these children and their families go through at the end of life would help us more successfully address their needs. [16] Fovcr example, the information given to parents at the time of diagnosis and treatment of their child's cancer should be provided more than once, as parents are only able to retain 
small amounts of information during periods of distress. [12, 41,43 ,55, 56, 57, 58] However, physicians worry about the extent to which their communication causes distress, particularly when they have to deliver very bad news. Substantial literature suggests that perhaps as a result of these feelings, physicians avoid giving clear and direct prognostic information. [13, 59, 60]

Health care practitioners could serve as facilitators in securing spiritual resources for those parents who may have difficulty securing them on their own. Offering a visit from the hospital's spiritual advisor or offering to contact their own spiritual advisor upon their behalf may be a start in securing necessary resources for them. [6] Health care professionals should provide ongoing assessment of adolescents' levels of hope, spiritual well-being (SWB) and its dimensions, and perceived stressors associated with the cancer experience and should plan interventions that foster use of SWB as a coping resource. 8

In facilitating a spiritual relationship for families in distress, health care professionals may themselves experience a certain degree of spiritual distress [61, 6]

According to Mack JW, Wolfe J, Cook EF, et al [62] parent's peace of mind was not associated with the child's physician-rated prognosis or with the amount of time that had elapsed since diagnosis but with high-quality information they receive from the health care team and with a strong sense of trust in the physician communication behavior including prognostic disclosure. [13]

Parents' intellectual and emotional awareness of their child's incurable disease appears to be influenced by the type and amount of information provided to them by their child's clinicians. $[62,63]$ Clinicians' reactions also influence parents' level of trust at a time when trust is essential to meet the child's and family's needs. [64, 65, 17]

To ensure that we as clinicians are aware of our patients' wishes, these issues should be sensitively explored early in the stage of illness when cognition and communication are not impaired.[16] Families who were linked with a supportive community physician and home care services believed that their needs were met and they were well supported at home. Families who did not have access to such a network often felt lost and abandoned. [16]

The health care team should not only do ethical obligation, but also in doing so they may be able to help alleviate the deep personal and existential suffering that parents experience as they care for their children with cancer. [13]

Hinds PS, Oakes LL, Hicks J, et al17 findings also indicate that parents benefited from their child's clinicians showing emotion about the child's clinical situation and telling them that they are good parents.

It has been suggested that nursing staff can be an integral part of this process by talking and listening to those who wish to discuss their spiritual beliefs; by engaging in prayer; and by mobilizing spiritual resources, when needed. $[66,1]$

Nurses may feel hesitant and awkward about initiating conversations that are related to spirituality, yet this is an important part of care. Children will talk about these topics especially with nurses with whom they've established a relationship. [15] Thus, nurses should consider developmental phase and gender when planning interventions to foster hope and spiritual well-being in adolescents' adaptations to the cancer experience. [19] Theymight use questions like "Some children while they are sick do things to feel close to God (or a higher power). Have you done anything like that? If so, what did you do?" or "Some children pray when they don't feel good or are unhappy. Do you pray?" guide to broach the subject of spirituality. [15]

According to Kerr LM, Harrison MB, Medves J, et al [12] and Hinds PS, Oakes LL, Hicks J, et al [17] parents' main requests the following:

- Clear, understandable, concise, complete, accurate, and compassionately delivered information. $[44,67,68,69]$ 
- Clinicians respect and support parent's wishes, decisions, and efforts.

- Staff shows emotion about child's clinical situation, allow parent to vent, and show sincere care for child and parent.

- Parents prefer that clinicians convey respect for parental religious beliefs.

- Getting a full explanation of every test and treatment procedure your child goes through.

- Having your oncologist pass on a positive sense of hope to you, your child, and family.

Taken together, these findings suggest that physicians can play an important role in helping parents come to terms with the child's illness. [13]

\section{Conclusion}

Pediatric cancer is a wide challenge for the patient, his/her family and the health care team. In this context they search several ways to find meaning for this journey facing anxiety, distress, hopeless, pain and sadness. Spirituality and faith, appear to be one of these ways, providing important factors in the childhood cancer journey. Much like a beacon serves to guide wayward ships in a storm, faith and spirituality can also serve as a guide during the often tumultuous journey of childhood cancer. 6

This review was capable to verify that spirituality is considered a source of well-being and hope and has helped in the better management of the cancer's limitating conditions.

However, this review's limitation comprehends the fact that very little has been published regarding the spirituality in childhood cancer management. Thus, further studies are needed to fulfill this gap in the health care arena. In this context, this review is able to increase the awareness of health care professionals about their responsibility to identify the right moment to offer pediatric cancer patients' families spiritual support, providing to the child an unabridged and more humanized care. This article also has as objective to help parents to find other ways to cope with the disease's spiritual, psychological and social effects, bringing a body of knowledge about how spirituality can be an alternative to relieve the pain and turn them into a more proactive and integrated within the context of health quality improvement.

\section{Acknowledgments}

We are grateful to the Suicidology Research group - Federal University of Ceará (UFC) / National Council for Scientific and Technological Development (CNPq). We would also like to thank the Scientific Writing Lab (LABESCI) - Faculty of Medicine, Federal University of Cariri (UFCA), and to the Laboratory of Scientific Methodology and Scientific Production (LAPESCI) - Faculty of Medicine, Estacio - FMJ. 


\section{References}

1. Woodgate RL, Degner LF. A Substantive Theory of Keeping the Spirit Alive: The Spirit Within Children With Cancer and Their Families. J Pediatr Oncol Nurs 2003; 20(3): 103-19.

2. Feyh JM, Levine GE, Clay K. Close Relatives Find Meaning to Cope With Cancer Diagnosis and Treatment of Family Members. Am J Hosp Palliat Care 2012; 29(8): 647-54.

3. Initiative for Pediatric Palliative Care. About IPPC. http://ippcweb.org/about.asp. Accessed January 5, 2010.

4. Lim J, Wong M, Chan MY, et al. Use of complementary and alternative medicine in paediatric oncology patients in Singapore. Ann Acad Med Singapore 2006; 35(11): 753-8.

5. Oxford English Dictionary. (2005). Oxford English dictionary online. Retrieved June 8, 2005, from http://80-www.lib. uwaterloo.ca.proxy.lib.uwaterloo.ca/uwonly/weboed.html Patton, M. Q. (2002). Qualitative research and evaluation methods (3rd ed.). Thousand Oaks, CA: Sage.

6. Schneider MA, Mannell RC. Beacon in the storm: an exploration of the spirituality and faith of parents whose children have cancer. Issues Compr Pediatr Nurs 2006; 29(1): 3-24.

7. Haase JE. The adolescent resilience model as a guide to interventions. J Pediatr Oncol Nurs 2004; 21(5): 289-99.

8. Hendricks-Ferguson V. Hope and spiritual well-being in adolescents with cancer. West J Nurs Res 2008; 30(3):385-401

9. American Academy of Pediatrics. Committee on Bioethics and Committee on Hospital Care: Palliative care for children. Pediatrics 2000; 106: 351-357.

10. Committee on Palliative and End-of-Life Care for Children and their Families: When Children Die: Improving Palliative and Endof -Life Care for Children and their Families. Washington, D.C.: National Academy Press, 2003.

11. Mack JW, Hilden JM, Watterson J, et al. Parent and physician perspectives on quality of care at the end of life in children with cancer. J Clin Oncol 2005; 23(36): 9155-9161.

12. Kerr LMJ, Harrison MB, Medves J, et al. Understanding the supportive care needs of parents of children with cancer: an approach to local needs assessment. J Pediatr Oncol Nurs 2007; 24(5): 279-93.

13. Mack JW, Wolfe J, Cook EF, et al. Peace of mind and sense of purpose as core existential issues among parents of children with cancer. Arch Pediatr Adolesc Med 2009; 163(6): 519-24.

14. Tamburro RF, Shaffer ML, Hahnlen NC, et al. Care goals and decisions for children referred to a pediatric palliative care program. J Palliat Med 2011; 14(5): 607-13.
15. Kamper R, Van Cleve L, Savedra M. Children with advanced cancer: responses to a spiritual quality of life interview. J Spec Pediatr Nurs 2010; 15(4): 301-6.

16. Zelcer S, Cataudella D, Cairney AE, Bannister SL. Palliative care of children with brain tumors: a parental perspective. Arch Pediatr Adolesc Med 2010; 164(3): 225-30.

17. Hinds PS, Oakes LL, Hicks J, et al. "Trying to be a good parent" as defined by interviews with parents who made phase I, terminal care, and resuscitation decisions for their children. J ClinOncol 2009; 27(35): 5979-85.

18. Servitzoglou M, Papadatou D, Tsiantis I, Vasilatou-Kosmidis $\mathrm{H}$. Quality of life of adolescent and young adult survivors of childhood cancer. J Clin Oncol 2009; 24(5): 415-22.

19. Hendricks-Ferguson V. Relationships of age and gender to hope and spiritual well-being among adolescents with cancer. J Pediatr Oncol Nurs 2006; 23(4): 189-99.

20. Cannaerta N, Dierck de Casterle B, Grypdonck, M. Palliative care, care for lifea study of the specificity of residential palliative care. Qual Health Res 2004; 14(6):816-835.

21. Contro NA, Larson J, Scofield S, et al. Hospital staff and family perspectives regarding quality of pediatric palliative care. Pediatrics 2004; 114(5): 1248-1252.

22. Kreicbergs $U$, Valdimarsdottir $U$, Onelov $E$, et al. Talking about death with children who have severe malignant disease. $\mathrm{N}$ Engl J Med 2004; 351(12): 1175-1186.

23. Haase JE, Heiney SP, Ruccione KS, Stutzer C. Research triangulation to derive meaning-based quality of life theory: Adolescent resilience model and instrument development. Int J Cancer Suppl 1999; 12: 125-31.

24. Hinds PS, Martin J. Hopefulness and the self-sustaining process in adolescents with cancer. Nurs Res 1988; 37(6): 336-40.

25. Peterman $A H$, Fitchett $G$, Brady MJ, et al. Measuring spiritual well-being in people with cancer: the functional assessment of chronic illness therapy-Spiritual Well-being Scale (FACIT-Sp). Ann Behav Med 2002; 24(1): 49-58.

26. Ray A, Block SD, Friedlander RJ, et al. Peaceful awareness in patients with advanced cancer. J Palliat Med 2006; 9(6): 13591368.

27.Jaarsma TA, Pool G, Ranchor AV, Sanderman R. The concept and measurement of meaning in life in Dutch cancer patients. Psychooncology 2007; 16(3): 241- 248.

28. Lethborg C, Aranda S, Cox S, Kissane D. To what extent does meaning mediate adaptation to cancer? The relationship between physical suffering, meaning in life, and connection to others in adjustment to cancer. Palliat Support Care 2007; 5(4): 377-88 
29. Steinhauser $\mathrm{KE}$, Voils $\mathrm{Cl}$, Clipp EC, et al. "Are you at peace?" one item to probe spiritual concerns at the end of life. Arch Intern Med 2006; 166(1): 101-105

30. Hart D, Schneider D. Spiritual care for children with cancer. Semin Oncol Nurs 1997; 13(4): 263-70.

31. Parry C, Chesler MA. Thematic evidence of psychosocial thriving in childhood cancer survivors. Qual Health Res 2005; 15(8): 1055-73.

32. Zebrack BJ, Chesler MA. Quality of life in childhood cancer survivors. Psychooncology 2002; 11: 132-41.

33. Fowler J. Stages of Faith. 1st edition. San Francisco, CA: Harper \& Row; 1981

34. Christ GH, Lane JM, Marcove R. Psychosocial adaptation of long-term survivors of bone sarcoma. Journal of Psychosocial Oncology 1995; 13(4): 1-22

35. Tebbi CK, Mallon JC, Richards ME, Bigler LR. Religiosity and locus of control of adolescent cancer patients. Psychol Rep 1987; 61(3): 683-96.

36. Soothill K, Morris SM, Harman JC, et al. Cancer and faith-Having faith: Does it make a difference among patients and their informal caregivers? Scandinavian Journal of Caring Sciences 2002; 16(3): 256-263.

37. Landolt MA, Vollrath M, Ribi K. Predictors of coping strategy selection in paediatric patients. ActaPaediatrics 2002; 91: 95460.

38. Hoekstra-Weebers JE, Jaspers JP, Kamps WA, Klip EC. Psychological adaptation and social support of parents of pediatric cancer patients: A prospective longitudinal study. J Pediatr Psychol 2001; 26(4): 225-35.

39. Martinson IM, Leavitt M, Liu C, et al. Comparison of Chinese and Caucasian families caregiving to children with cancer at home: Part I. J Pediatr Nurs 1999; 14(2): 99-109.

40. Martinson IM, Liu-Chiang CY, Yi-Hua L. Distress symptoms and support systems of Chinese parents of children with cancer. Cancer Nurs 1997; 20(2): 94-9

41. Santacroce S. Uncertainty, anxiety, and symptoms of posttraumatic stress in parents of children recently diagnosed with cancer. J Pediatr Oncol Nurs 2002; 19(3): 104-11.

42. Sawyer M, Antoniou G, Toogood I, et al. Childhood cancer: a 4-year prospective study of the psychological adjustment of children and parents. J Pediatr Hematol Oncol 2000; 22(3): 21420.

43. Shields G, Schondel C, Barnhart L, et al. Social work in pediatric oncology: a family needs assessment. Soc Work Health Care 1995; 21(1): 39-54

44. Hinds PS, Oakes L, Furman W, et al. Decision making by parents and health care professionals when considering continued care for pediatric patients with cancer. Oncol Nurs Forum 1997; 24(9): 1523-8

45. Robinson MR, Thiel MM, Backus MM, Meyer EC. Matters of spirituality at the end of life in the pediatric intensive care unit. Pediatrics 2006; 118(3): 719-29.
46. Kreichbergs $U$, Valdimarsdottir $U$, Onelov $E$, et al. Care related distress: a nationwide study of parents who lost their child to cancer. J ClinOncol 2005; 23(36): 9162-71.

47.Committee on Palliative and End-of-Life Care for Children and their Families: When Children Die: Improving Palliative and Endof -Life Care for Children and their Families. Washington, D.C.: National Academy Press 2003.

48. Jenkins RA, Pargament KI. Religion and spirituality as resources for coping with cancer. J psychosocOncol 1995; 13: 51-74.

49. Cassel EJ. The nature of suffering and the goals of medicine. $\mathrm{N}$ Engl J Med 1982; 306(11): 639-45.

50. Fife BL. The role of constructed meaning in adaptation to the onset of life- threatening illness. SocSci Med 2005; 61(10): 21322143.

51. Mack JW, Hilden JM, Watterson J, et al. Parent and physician perspectives on quality of care at the end of life in children with cancer. J Clin Oncol 2005; 23(36): 9155-9161.

52. Barbarin OA, Chesler $M$. The medical context of parental coping with childhood cancer. Am J Community Psychol 1986; 14(2): 221-35.

53. Fletcher PC, Clarke J. When your child has cancer: A discussion of factors that affect mothers' abilities to cope. J Psychosoc Oncol 2003; 21(3): 81-99.

54. Spilka B, Zwa,rtjes WJ, Zwartjes GM. The role of religion in coping with childhood cancer. Pastoral Psychology 1991; 39(5): 295-304

55. Buckley, M. Childhood cancer: Meeting the information needs of families. Paediatric Nursing 2000; 12: 22-23.

56. Chesler MA, Parry C. Gender roles and/or styles in crisis: an integrative analysis of the experiences of fathers of children with cancer. Qual Health Res 2001; 11(3): 363-84.

57.Eden OB, Black I, MacKinlay GA, Emery AE. Communication with parents of children with cancer. Palliat Med 1994; 8(2): 105-14.

58. Enskär K, Carlsson M, Golsäter $M$, et al. Parental reports of changes and challenges that result from parenting a child with cancer. J PediatrOncolNurs 1997; 14(3): 156-63.

59. Christakis NA, Lamont EB. Extent and determinants of error in doctors' prog- noses in terminally ill patients: a prospective cohort study. BMJ 2000; 320 (7233): 469-472

60. The AM, Hak T, Koëter G, Wal GVD. Collusion in doctor-patient communication about imminent death: an ethnographic study. West J Med 2001; 174(4): 247-53.

61. Hart D, Schneider D. Spiritual care for children with cancer. SeminOncolNurs 1997; 13(4), 263-270

62. Mack JW, Wolfe J, Cook EF, et al. Hope and prognostic disclosure. J ClinOncol 2007; 25(35): 5636-42.

63. Valdimarsdottir $U$, Kreichbergs $U$, Hauksdottir A, et al. Parents' intellectual and emotional awareness of their child's impending death to cancer: A population-based long-term follow-up study. Lancet Oncol 2007; 8(8): 706-14. 
64. Hinds $P$, Oakes L, Furman W. End-of-life decisions in pediatric oncology, in Ferrell BR, Coyle N (eds): Textbook of Palliative Nursing. New York, NY, Oxford University Press 2001.

65. Meert KL, Thurston CS, Briller SH. The spiritual needs of parents at the time of their child's death in the pediatric intensive care unit and during bereavement: A qualitative study. PediatrCrit Care Med 2005; 6(4): 420-7.

66. Taylor EJ Nurses caring for the spirit: Patients with cancer and family caregiver expectations. Oncology Nursing Forum 2003; 30(4), 585-90.

67. Monterosso L, Kristjanson LJ. Supportive and palliative care needs of families of children who die from cancer: An Australian Study. Palliat Med 2008; 22(1): 59- 69.

68. Tomlinson D, Capra M, Gammon J, et al. Parental decision making in pediatric cancer end-of- life care: Using focus group methodology as a prophase to seek participant design input. Eur J OncolNurs 2006; 10: 198-206.

69. Meert KL, Eggly S, Pollack M, et al. Parents' perspectives on physician-parent communication near the time of a child's death in the pediatric intensive care unit. PediatrCrit Care Med 2008 ;9(1): 2-7.

\section{Comment on this article:}

\section{(f) (B) in $8+\mathbf{S}$ P}

Tr

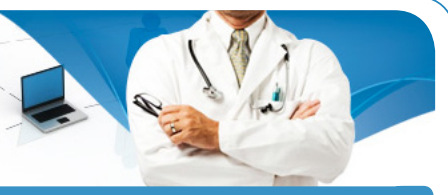

http://medicalia.org/

Where Doctors exchange clinical experiences, review their cases and share clinical knowledge. You can also access lots of medical publications for free. Join Now!

\section{Publish with iMedPub}

\section{http://www.imed.pub}

International Archives of Medicine is an open access journal publishing articles encompassing all aspects of medical science and clinical practice. IAM is considered a megajournal with independent sections on all areas of medicine. IAM is a really international journal with authors and board members from all around the world. The journal is widely indexed and classified Q1 in category Medicine. 